\title{
Investigation of the Antioxidant Effect of Hungarian White Wines and Tokaj Wine Specialities
}

\author{
Kállay M. ${ }^{1}$, Török Z. ${ }^{1}$ \& Korány K. ${ }^{2}$ \\ 'University of Horticulture and Food Industry, Department of Enology \\ H-1118 Budapest, Ménesi út 45. \\ ${ }^{2}$ University of Horticulture and Food Industry, Department of Food \\ Chemistry and Nutrition \\ H-1118 Budapest, Somlói lut 14-16.
}

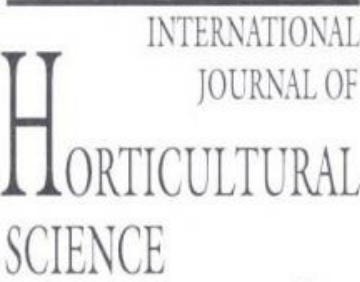

AGROINFORM

Publishing House, Hungary

Key words: Total Antioxidant Status (TAS), total polyphenol, leucoanthocianin, catechin, resveratrol determination

Summary: Authors investigated the antioxidant effect of wine-phenolics, expressed as total antioxidant status (TAS-value). This property may play an important role in elimination of the harmful effects of free radicals in human body.

Independently of their polyphenol composition, special quality Tokaj wines did not show extremely high TAS-values. In Tokaj Aszu wines the total antioxidant status was independent of the "puttony" number but was influenced by the length of aging time.

\section{Introduction}

Free radicals are considered responsible for many illnesses of human body (Hallwell et al., 1989). Several scientific investigations deal with the inhibition of the disavantageous reactions of these harmful substances (Riemerama et al., 1991; Stampfer et al., 1993; Rimm et al., 1993). Results promise the possibility of reducing the unhealthy effects of radicals by introducing antioxidant agents into the human organism. Kinsella et al. (1993) discussed in details the probable defensive role of antioxidants in obstructing the formation of cardiovascular and cancerogeneous illnesses. Due to their hypothesis flavonoids of plant origin possess significant antioxidant protecting characteristics. These compounds strongly connect with low density lipoproteins (LDLs) and behave like endogeneous antioxidant (Vitamin-E, Vitamin-C) analogs (Vinson et al., 1995). In other words they inhibit the oxidation of LDLs that might cause arteriosclerosis. An American research team has established, that polyphenols occuring in wines potentially have antioxidant activity as well (Esterhauer et al., 1992; Frankel et al., 1993; Frankel et al., 1995). Comparing the the antioxidant effect of red and white wines and Vitamin- $\mathrm{C}$ in vivo experiments it has been stated, that just after consumption ascorbic acid increased the blood serum antioxidant capacity by $22-29 \%$, red wine raised it by $18 \%$ as an average, and in the case of white wine the value was 4-7 \% (Whitehead et al., 1995).
A vast body of Hungarian enological research deals more and more with the world famous Tokaj Aszu wines. Tokaj wine-growing district extends in the north-eastern part of Hungary. Unique quality 3, 4, 5, 6 puttony (hod or backbasket) Tokaj Aszu wines became famous for the pourriture noble caused by Botrytis cinerea. Under proper weather conditions whole ripe grapes infected by Botrytis go dry on the vine. During this fermentation process unique bouquet substances (aromatic taste and flavour compounds) develop. Aszu wine making starts with the exposure of the aszu grapes. Then the aszu mash due to the puttony number in amount (e.g. in case of 3 puttony aszu wine: $60 \mathrm{~kg}$ aszu mash to $1 \mathrm{hl}$ wine) is extracted with young wine or must for 24-48 hours and fermented afterwards (Eperjesi et al., 1998). Aszu wines have been supposed to possess curative power for a long time. At the begining of the century they were indicated for anaemia and lack of appetite. Aszu wine is effective against sudden cardiac decompensation due to its high glucose content and has got relatively large amount of vitamins (Ambróczy, 1932), though wines are not considered remarkable vitamin sources. The Hungarian Medicine Administration book written by Issekutz suggests it for its roborant-curing effect (Issekutz, B., Issekutz, L, 1975).

As for the role of free radicals, our work aimed at the confirmation and proof of the medical power of Tokaj wines experimentally, furthermore the influence of polyphenolic content, vintage and puttony number on antioxidative status has been studied. 


\section{Materials and methods}

The white wines derived from Eger, Tokaj wine growing district and Badacsony. Among Tokaj wine uniquities sweet szamorodni and $3,4,5$ puttony aszu wines have been examined. The effect of vintages was followed by the proper selection of the samples. The total polyphenol, catechin and leucoanthocyanin contents of the wines were determined by the routine methods of the enological analytical practice.

The cis- and trans-resveratrol concentration was measured by direct HPLC injection (Kállay-Török, 1997).

The Total Antioxidant Status, called TAS afterwards, was determined by a special test produced by the RANDOX firm. The method is routinely applied in human medical practice for the determination of the antioxidant state of blood serum. The determination is based on measuring at $600 \mathrm{~nm}$ the absorbance of the stable blueish-green colour of a cation type free radical, formed by a peroxidase (methmyoglobin) enzyme coupled substance (2,2' -azino-di(3-ethylbenzthiazoline-sulphonate) in the presence of $\mathrm{H}_{2} \mathrm{O}_{2}$. If the sample contains antioxidant components the decrease of the absorbance is proportional to their concentration. The antioxidant state of the samples have been expressed in $\left[\mathrm{mMol} / \mathrm{dm}^{3}\right]$ as the equivalent of the standard 6-hydroxi-2,5,7,8-tetramethylcromane-2-Carboxilic acid. In measuring white wines' TAS no special sample preparation was necessary.

The TAS values of the traditional antioxidant-like ascorbic and sulphurous acids have also been determined because they might have an influence on the results and might alter the effect of phenolic compounds.

In the evaluation of the result Microsoft Excel 5.0 and Statgraf 5.1 softwares have been used.

\section{Results and discussion}

In our investigations the TAS values of the traditional antioxidants applied in enology and beverage technology have been measured. The results are summarized in Table $I$.

Table 1 - TAS values of the traditional antioxidants and catechin

\begin{tabular}{l|c|c}
\hline Compound & Concentration $\left[\mathrm{mg} / \mathrm{dm}^{3}\right]$ & TAS $\left[\mathrm{mMol} / \mathrm{dm}^{3}\right]$ \\
\hline $\mathrm{SO}_{2}$ (free) & 100 & 0.04 \\
Ascorbic acid & 100 & 0.14 \\
Catechin & 100 & 1.18 \\
\hline
\end{tabular}

Due to the results it can be stated, that at the concentration of application the antioxidant status of ascorbic and sulphurous acids is low $\left(0.04-0.14 \mathrm{mMol} / \mathrm{dm}^{3}\right)$. Compared to them, that of the catechin is surprisingly high $(1.18$ $\left.\mathrm{mMol} / \mathrm{dm}^{3}\right)$. This fact suggests, that the role of sulphurous acid present in a concentration that matches the GMP of enology is insignificant, when determining the TAS of wines. The antioxidant state is decisively determined by the catechin content and other phenolic compounds possessing antioxidant activity. The unusually low values measured for the traditional antioxidants must be connected to the specifity of the measurement.

The relationship between the TAS values and the major polyphenolic compounds were studied by linear regression. It has been established, that total polyphenolic content is in close connection with the antioxidative status $(r=0.82)$.

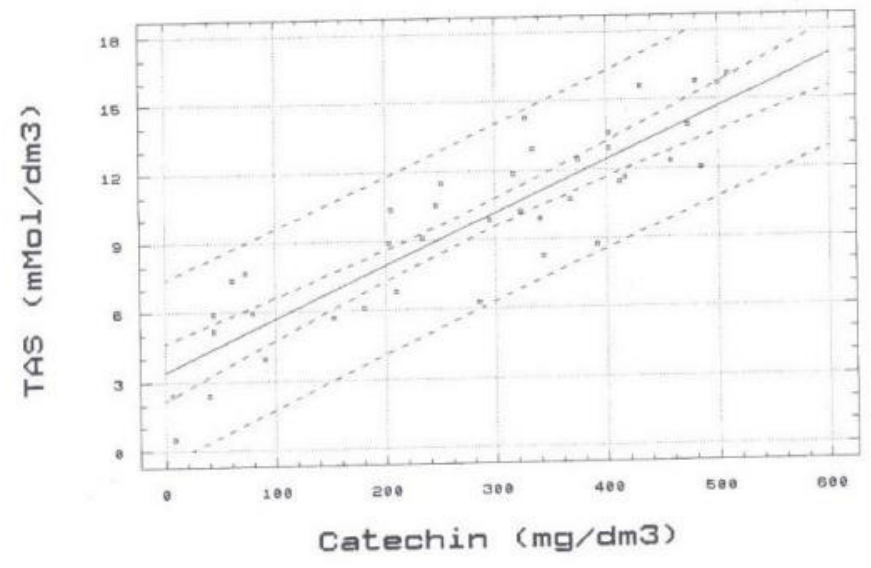

Figure 1 Linear regression analysis of the correlation between catechin contents and TAS-values

Figure $I$ depicts the connection between catechin content and TAS. The correlation coefficient is 0.93 that means very close connection. The results of the investigations of the other compounds' role show, that the TAS-value is influenced the least by the resveratrole concentration, but leucoanthocianins and anthocianins present in red wines have a greater effect. The examination of the polyphenolic content and TAS-values of individual wines proves, that high TAS does not mean inevitably high polyphenolic or catechin content. Polyphenolic constituents presumably possess synergic features, furthermore other components might play role in forming the antioxidative status the investigation of that is of great importance.

\section{The determination of the antioxidative status of white wines}

The results of seven samples deriving from the three wine producing district mentioned are in the interval $0.38-0.89$ $\mathrm{mMol} / \mathrm{dm}^{3}$, with an average of $0.57 \mathrm{mMol} / \mathrm{dm}^{3}$ ( $\mathrm{s}=0.03$ ).

Outstandingly high value, $1.81 \mathrm{mMol} / \mathrm{dm}^{3}$ was measured for the Leanyka from Eger, vintage 1996. Comparing its polyphenolic composition to that of the other Leanyka from Eger vintage 1997, the conclusion can be drawn, that its total polyphenol, catechin and leucoanthocianin content is lower as Figure 3 shows. Consequently the extra-high antioxidant value is not necessarily accompanied with high polyphenolic content. Our research is intended to be conducted into this direction as well, 


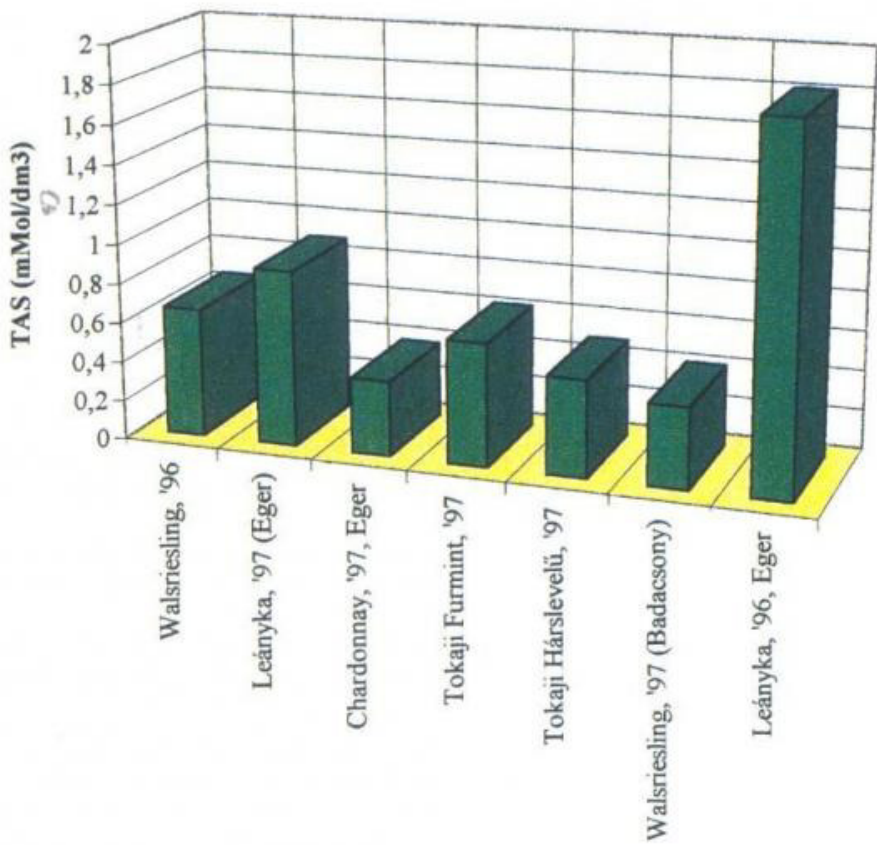

Figure 2 The TAS-values of the white wines examined

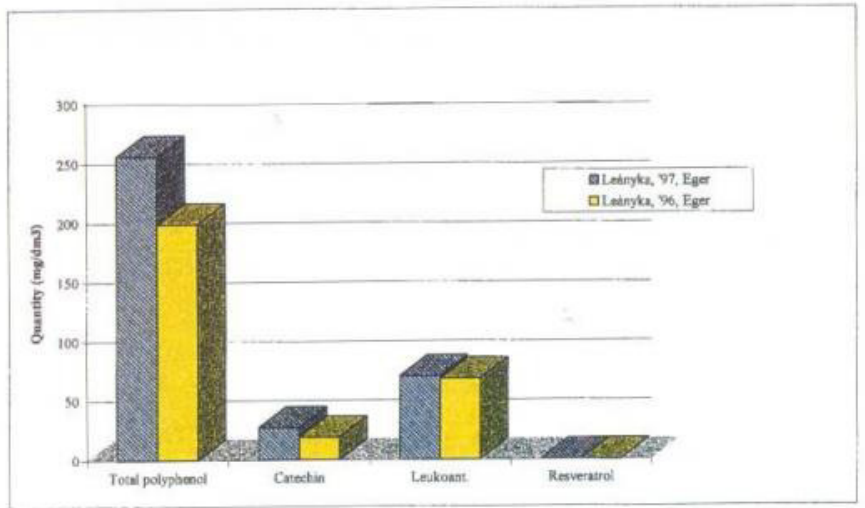

Figures 3 Polyphenol composition of Leányka wines deriving from Eger district

\section{The determination of the antioxidative status of Tokaj wine uniquities}

The TAS-values of 16 aszu and 1 sweet szamorodni wines have been measured. The results can be found in Table 2 .

Due to the results, the TAS of sweet szamorodni wine is $0.74 \mathrm{mMol} / \mathrm{dm}^{3}$ that approaches the antioxidant state of white wines. The probable cause of this phenomenon is the szamorodni production technology, where intact and aszu grapes are processed together in a large mass without any selection. The wine produced by this method contains less aszu grapes and its composition is more similar to special quality white wines made of over-ripe grapes than to aszu wines.

The TAS-value of aszu wines was $1.92 \mathrm{mMol} / \mathrm{dm}^{3}$ as an average $(s=0.10)$, three times higher than that of white wines. The explanation is hidden partly in the technology,
Table 2 - The TAS-values of Tokay wine uniquities

\begin{tabular}{l|c|c}
\hline Sample & Vintage & TAS $\left[\mathrm{mMol} / \mathrm{dm}^{3}\right]$ \\
\hline 6 puttony aszu & 1995 & 1.45 \\
5 puttony aszu & 1992 & 2.68 \\
5 puttony aszu & 1993 & 1.93 \\
5 puttony aszu & 1993 & 2.10 \\
5 puttony aszu & 1995 & 1.79 \\
5 puttony aszu & 1996 & 1.80 \\
5 puttony aszu & 1997 & 1.80 \\
4 puttony aszu & 1988 & 0.44 \\
4 puttony aszu & 1992 & 2.60 \\
4 puttony aszu & 1993 & 1.95 \\
4 puttony aszu & 1995 & 1.80 \\
4 puttony aszu & 1996 & 1.79 \\
4 puttony aszu & 1997 & 1.78 \\
3 puttony aszu & 1995 & 1.79 \\
3 puttony aszu & 1996 & 1.81 \\
3 puttony aszu & 1997 & 1.79 \\
Szamorodni (sweet) & 1994 & 0.74 \\
\hline
\end{tabular}

partly in the polyphenolic composition. In aszu wine making aszu grapes are extracted for $24-48$ hours. The total polyphenolic content extracted during this time is threefold higher compared to the white wines. The differenece is much larger considering the catechin and leucoanthocianin content. The catechin concentration of aszu wines is five times higher and the leucoanthocianin content is twentyfold larger than that of the white wines. The average total polyphenol, catechin and leucoanthocianin contents of the examined aszu and white wine samples are summed up in Table 3.

Table 3-The average polyphenol, catechin and leucoanthocianin contents of the examined aszu and white wine samples.

\begin{tabular}{lccc}
\hline Wine & $\begin{array}{c}\text { Total polyphenol } \\
{\left[\mathrm{mg} / \mathrm{dm}^{3}\right]}\end{array}$ & $\begin{array}{c}\text { Catechin } \\
{\left[\mathrm{mg} / \mathrm{dm}^{3}\right]}\end{array}$ & $\begin{array}{c}\text { Leucoanthocyanin } \\
{\left[\mathrm{mg} / \mathrm{dm}^{3}\right]}\end{array}$ \\
\hline Aszu wines & 679.5 & 94.4 & 1390.1 \\
White wines & 225.5 & 17.14 & 68.7
\end{tabular}

The antioxidant status of aszu wines is affected by several factors. In our experiments the influence of technology. puttony-number and the age of wine has been analysed. The effect of technology is well represented by a 4 puttony aszu wine of 1988 vintage. This vintage was outstandingly excellent. Technology was able to save and transfer all the treasures of the aszu grapes. It has to be noted that technology at that time contained and applied more oxidative operations. The antioxidative state of this wine was $0.44 \mathrm{mMol} / \mathrm{dm}^{3}$, much lower than in the other aszu wines. This big diferrence could partly be explained by the alterations of the polyphenol composition and maturation time only. The antioxidant agents of the wine were exposed to greater oxidative effect by the technology of that time.

The influence of puttony number has been studied by two variable variance-analysis. We wanted to answer the question, how the puttony number change alters the TAS-value, more exactly, the TAS-averages belonging to definite puttony numbers differ significantly or not. Figure 4 represents the effect of puttony number on TAS. In the case of six- 


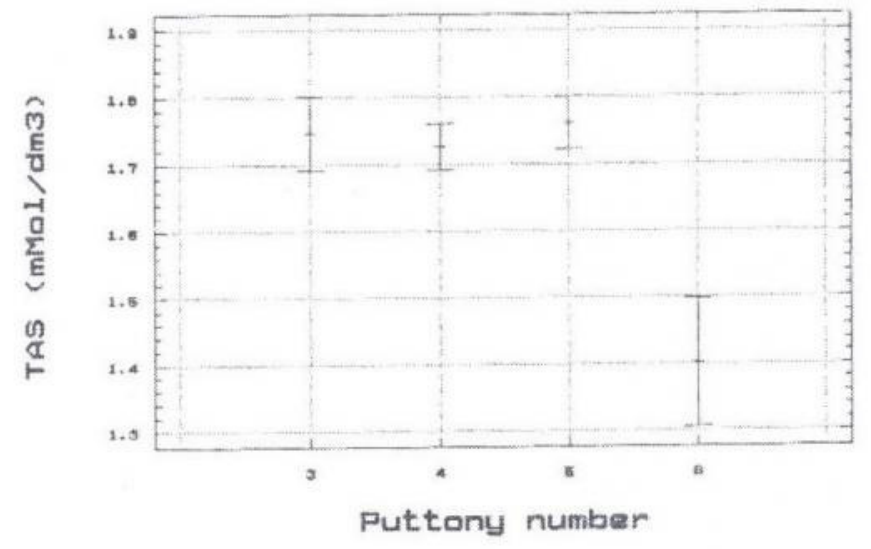

Figure 4 The effect of puttony number on TAS-values of Tokaj Aszu wines

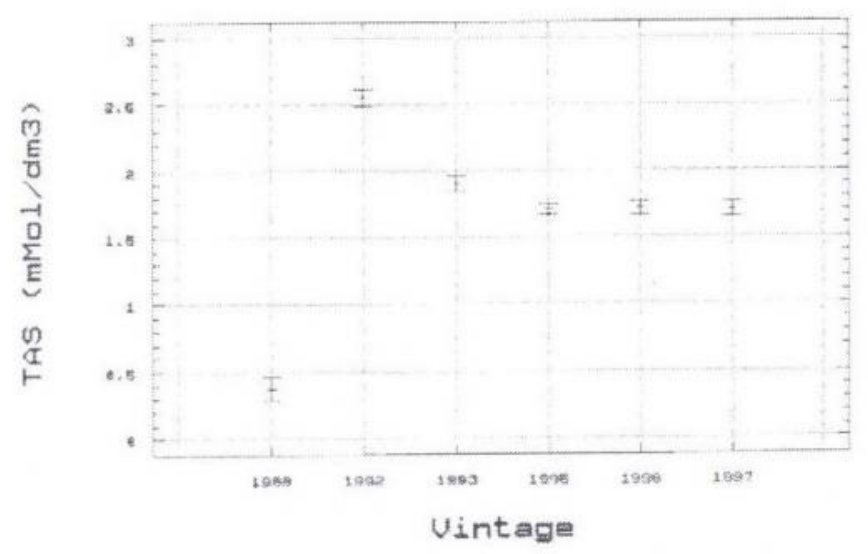

Figure 5 The effect of maturation time on Tokay Wines' TAS-values

puttony aszu wine only one measurement could be carried out, therefore no srict conclusion was drawn.

The results of 3,4 and 5 puttony aszu wines prove that no significant difference exists. Averages shown on the figure represent the TAS-values measured in the examined puttony number aszu wines and the limits mean the least significant differences at $95 \%$ probability level. Summing up the results of mathematical-statistical analysis it can be stated, that hod number has does not affect the antioxidant status of aszu wines.

The effect of maturation time on TAS-values has also been studied by two variable variance-analysis. The investigated samples derived from the vintages 1988, 1992, 1993, 1995. 1996 and 1997. In this case the question was, if the maturation time affected the TAS-values, in other words, do the TAS-averages of the aszu wines of the diferrent vintages deviate significantly at the moment of the measurement, or not. The TAS-averages of the vintages 1993, 1992 and 1988 differ significantly at $95 \%$ probability level. It can be observed that the antoxidant status of young (1-3 year old) wines does not differ significantly, but in the case of 4 year old or older wines the difference is definite. The age (old vintage) is not accompanied with low TAS-values necessarily, for instance, the antioxidative status of 4 and 5 puttony aszu wines from the 1992 vintage was the highest ( 2.6 and 2.68 $\mathrm{mMol} / \mathrm{dm}^{3}$ ) among the samples investigated. Based on the mathematical-statistical analysis the conclusion can be drawn, that maturation time has got a significant effect on the antioxidative state of aszu wines. Our preliminary results suggest that 1-3 year old Tokaj Aszu wines possess identical TAS-values practically, while the antioxidative status of older wine uniquities shows a decrease. The shape of the curve indicates periodical, trend-like changes, the more exact determination of that is intended to be performed in the near future with a greater sample number.

\section{Conclusion}

The results of scientific investigations prove, that the polyphenolic compounds of wines have got antioxidant activity. For this characteristic, they might play a very important role in the inactivation of free radicals damaging human organism. Based on our work it has been stated that the unusually low values measured for the traditional antioxidants used in enology and beverage technology must be connected to the specifity of the measurement. The total antioxidant status of the examined Hungarian white wines was $0.573 \mathrm{mMol} / \mathrm{dm}^{3}$ as an average. It could be observed, that extereme high TAS-values are not inevitably accompanied with high total polyphenol content neither with large leucoanthocianin and catechin amounts. It could be established that the antioxidant status of szamorodni is closer to the TAS of the white wines $\left(<1.0 \mathrm{mMol} / \mathrm{dm}^{3}\right)$ among Tokaj wine uniquities, while that of aszu wines are much higher (average $1.92 \mathrm{mMol} / \mathrm{dm}^{3}$ ). This feature can be explained by the higher polyphenol content compared to white wines and the different technology. In forming the antioxidative status several factors play role. Beside the quality and quantity of phenolic compounds possessing antioxidant activity, TASvalues are also influenced by the wine making technology, because during grape processing and maturation different oxidative effects might occure in the wines. Among the polyphenolic fractions examined, TAS is affected by the catechin content to the highest extent, leucoanthocianins have smaller influence and also the anthocianins in the case of red wines. Resveratrol virtually has got no effect on this parameter. The quantity and composition of antioxidative polyphenols change during storage in the consequence of oxidation, polymerization and other reactions. Both the starting concentration of TAS forming substances and the maturation technology play role in change of antioxidative status during maturation. Besides, TAS is affected by maturation time as well. In case of Tokaj Aszu wines puttony number has got no influence on TAS.

\section{References}

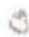

Ambróczy Á. (1932): Tokaj-hegyalja és néhány szellemtörténeti vonatkozása. A központi sajtóvállalat kiadása. Budapest, 22-23. 
Eperjesi I., Kállay M., Magyar (1998): Borászat, Mezōgazda, Bp.

Frankel, E.N., Waterhouse, A.L., Teisseidre, P.L. (1995): Principal Phenolic Phytochemicals in selected California Wines and Their Antioxidant Activity in Inhibiting Oxidation of Human Losh-Density Lipoproteins. J. Agric. Food. Chem., 43, 890-894.

Hallwell, B., Gutteridge, J.M.C. (1989): Free radicals in biology and medicine. Second ed. Oxford: Clarendon Press, 416-94.

Issekutz, B., Issekutz, L. (1975): Gyógyszerrendelés. Medicina Kiadó, Budapest

Kállay M., Török Z. (1997): Determination of resveratrol isomers in Hungarian wines. Horticultural Science, 29. (3-4), 78-83.

Riemerama, R. A., Wood, D.A., MacIntyre, C.CA., Elton, R.A., Gey, F.K., Oliver, M.F. (1991): Risk of angina pectoris and plasma concentration of vitamins $\mathrm{A}, \mathrm{C}$ and $\mathrm{E}$ and carotene. Lancet $337,1-5$.
Rimm, E.B., Stampfer, M.J., Ascherio, A., Giovannmucci, E., Colditz, E., Willett, W.C. (1993): Vitamin E consumption and the risk of coronary artery disease in men. N. Eng. J. Med., 328. 1450-1456,

Stampfer, M.J., Hennekens, C.H., Manson, J.E., Colditz, G.A., Rosner, B., Willett, W.C. (1993): Vitamin E consumption and the risk of coronary artery disease in women. N. Engl. J. Med., 328. 1444-1449.

Teisseidre, P.L., Waterhouse, A.L., Walzem, R.L., German, J.B., Frankel, E.N., Ebeler., Clifford, A.J. (1995): Composés phénoliques du Raisin et du Vin et Santé. Bulletin de l' O.I.V., 781782., 251-275.

Whitehead, T.P., Robinson, D., Allway, J., Syms, J., Hale, A. (1995): Effect of Red Wine Ingestion on the Antioxidant Capacity of Serum. Clin. Chem. 41/1. 32-35. 